\title{
Bioenergetic Assessment and Economic Efficiency of Predecessors and Fertilizer Systems in the Cultivation of Winter Wheat
}

\author{
Nikolay Nikolaevich Neshchadim ${ }^{1 *}$, Aleksandr Alekseevich Kvashin $^{1}$, Ksenia Nikolaevna Gorpinchenko ${ }^{1}$, Yuriy \\ Petrovich Fedulov ${ }^{1}$, Anatoliy Alekseevich Salfetnikov ${ }^{1}$ \\ ${ }^{I}$ Kuban State Agrarian University, Kalinina St., 13, Krasnodar, 350044, Russia \\ *Corresponding author E-mail: neshchadim.n.n@mail.ru
}

\begin{abstract}
The influence of a type of crop rotation, the predecessor and various doses of mineral fertilizers on the yield of winter wheat was examined. The studies were conducted at the North Kuban Agricultural Experimental Station in two 10-field rotations - grain tillage and grain-grass tillage - in the course of a prolonged stationary experiment. The soil was ordinary chernozem, low in humus, deep, with the humus content in the arable $(0-30 \mathrm{~cm})$ soil layer equaling to $3.95-4.00 \%$ depending on the nutrient status, the content of mineral nitrogen equaling to $5.9-8.3 \mathrm{mg} / \mathrm{kg}$ of soil, and the content of exchangeable potassium equaling to $330-360 \mathrm{mg} / \mathrm{kg}$ of soil.

It has been established that from the point of view of bioenergetic and economic efficiency, the most favorable predecessors for cultivation of winter wheat should be considered sainfoin and winter wheat, and for the rotation of sainfoin - peas. Maize harvested for grain and sugar beet are more time-consuming and energy-consuming tillage predecessors. Among the applied fertilizer systems, the best economic and bioenergetic indicators were obtained by using medium and higher doses of complete mineral fertilizer.
\end{abstract}

Keywords: Bioenergetic assessment; Correlation coefficient; Crop rotation; Economic efficiency; Fertilizer dose; Predecessor; Variety; Winter wheat; Yield.

\section{Introduction}

When cultivating any crop, including winter wheat, the yield, as well as the efficiency of production, are the determinative factors [1]. The economic feasibility of growing winter wheat is the determining factor for sustainable development for most regions $[2$, $3,4]$.

The costs of cultivation consist of many factors: the costs of creating a variety and seed production [5,6], development of new technologies $[7,8,9]$, the use of new agricultural machinery and chemical plant protection $[10,11,12,13]$. Soil and favorable weather conditions are also important $[14 ; 15 ; 16]$.

One of the most important properties of winter wheat, which determines its place in crop rotation, is the reaction to a change in the agricultural background. Given the fact that among grain crops, winter wheat is the most demanding for soil fertility, low agricultural background is the cause of decline, and the optimal one contributes to an increase in the grain yield [8; 15].

In this connection, the use of fertilizers in agriculture should be economically profitable and energetically expedient. The share of fertilizers in the yield increase considerably varies. According to the data of many researchers, in the structure of energy expenses of crop production, the most cost-intensive items are fertilizers $44.5-56.5 \%$, combustive and lubricating materials $-17-22 \%$, operating costs of the machine and tractor fleet, buildings and constructions $-11-22 \%$, as well as seed grain [17].

To solve this problem, both economic and bioenergetic assessment of crop cultivation technologies is proposed, which allows determining the most rational methods of using natural resources on the basis of the received and expended energy [18]. Economic and bioenergetic assessment of technological methods of agricultural production permits to choose resource-saving technologies, reducing material and technical costs.

\section{Methods}

The studies were conducted in the northern zone of Krasnodar Krai. Soils of this region are formed under the conditions of warm summer, dry autumn and often warm winter. These factors contribute to the active decomposition of organic matter of plant residues in the soil, the formation of humic substances and their distribution in the soil profile.

At the same time, ordinary chernozems are characterized by low content of humus (4.5-5.5\%) and a considerable thickness of the humus horizon. The content of total nitrogen is in the range of $0.22-0.33 \%$, and the content of phosphorus is $0.16-0.19 \%$. The content of potassium in ordinary chernozem is $8-10$ times higher than the stock of nitrogen and phosphorus.

The research program included studying the effect of the crop rotation pattern, the predecessor and fertilizer systems on the yield of winter wheat and the technological quality of commercial products, as well as on the economic efficiency.

The research was conducted at the North Kuban Agricultural Experimental Station in two 10-field rotations: grain tillage (GT) and grain-grass tillage (GGT) ones. Crop rotation in GT was as follows: winter wheat - winter wheat - sugar beet - winter wheat maize for grain - peas - winter wheat - sunflower - spring barley - maize for grain; in GGT: winter wheat - sugar beet - winter 
wheat - maize for grain - peas - winter wheat - sunflower spring barley with complementary seeding under the cover of sainfoin - sainfoin (for seeds) - winter wheat.

The fertilizer was introduced according to the following scheme: 1 - without fertilizers (control); 2 - average dose of PK $\left(\mathrm{P}_{60} \mathrm{~K}_{0}\right) ; 3$ average dose of NK $\left(\mathrm{N}_{40} \mathrm{~K}_{0}\right) ; 4$ - average dose of NP $\left(\mathrm{N}_{40} \mathrm{~K}_{60}\right) ; 5$ minimal dose of NPK $\left(\mathrm{N}_{20} \mathrm{P}_{30} \mathrm{~K}_{0}\right) ; 6$ - average dose of NPK $\left(\mathrm{N}_{40} \mathrm{P}_{60} \mathrm{~K}_{0}\right) ; 7$ - elevated dose of NPK $\left(\mathrm{N}_{80} \mathrm{P}_{120} \mathrm{~K}_{0}\right)$. The total area of the land plot was $190 \mathrm{~m}^{2}$; the accounting area was $108 \mathrm{~m}^{2}$. The repetition of the experiment was 4 -fold.

\section{Results and Discussion}

The obtained yield data showed great importance of all the basic elements of mineral nutrition in the formation of the winter wheat yield. In some years, the difference in yield from a unit area, with the exclusion of these nutrients from the fertilizer composition, reached 2.59 ton/ha (Table 1 ).

Table 1: Yield of winter wheat, depending on the crop rotation, the predecessor and fertilizer systems, balanced by nutrient elements, ton/ha

\begin{tabular}{|c|c|c|c|c|c|c|c|}
\hline \multirow{2}{*}{ Fertilizer system } & \multicolumn{4}{|c|}{ Predecessor } & \multirow{2}{*}{ Average in the fertilizer system } & \multicolumn{2}{|c|}{ Increment to control } \\
\hline & maize, sainfoin & winter wheat & peas & sugar beet & & ton/ha & $\%$ \\
\hline \multicolumn{8}{|c|}{ grain tillage rotation } \\
\hline Without fertilizers (control) & 2.85 & 3.58 & 4.41 & 3.05 & 3.47 & & \\
\hline Minimal dose of NPK & 4.07 & 5.02 & 5.38 & 4.32 & 4.70 & 1.23 & 35.4 \\
\hline Average dose of NPK & 5.56 & 6.52 & 6.31 & 5.52 & 5.88 & 2.41 & 69.4 \\
\hline Elevated dose of NPK & 6.20 & 6.16 & 6.30 & 6.24 & 6.22 & 2.75 & 79.2 \\
\hline High dose of NPK & 6.16 & 5.94 & 6.22 & 6.12 & 6.11 & 1.76 & 16.1 \\
\hline Average for the predecessor & 4.97 & 5.36 & 5.72 & 5.05 & 5.28 & & \\
\hline $\mathrm{MSD}_{05}$ & 0.42 & 0.47 & 0.52 & 0.43 & & & \\
\hline \multicolumn{8}{|c|}{ grain-grass tillage rotation } \\
\hline Without fertilizers (control) & 5.41 & 4.11 & 4.65 & 3.34 & 4.38 & & \\
\hline Minimal dose of NPK & 6.17 & 5.11 & 5.42 & 4.43 & 5.28 & 0.90 & 20.5 \\
\hline Average dose of NPK & 6.36 & 5.55 & 6.13 & 5.67 & 5.93 & 1.55 & 35.4 \\
\hline Elevated dose of NPK & 6.41 & 5.81 & 6.46 & 6.12 & 6.20 & 1.82 & 41.5 \\
\hline High dose of NPK & 6.43 & 5.82 & 6.37 & 6.06 & 6.17 & 1.79 & 40.9 \\
\hline Average for the predecessor & 6.16 & 5.28 & 5.81 & 5.12 & 5.59 & & \\
\hline $\mathrm{MSD}_{05}$ & 0.50 & 0.52 & 0.55 & 0.39 & & & \\
\hline
\end{tabular}

Despite the fact that ordinary chernozem has a high rate of exchange potassium, systematic exclusion of this nutrition element from the composition of fertilizers leads to a decrease in the yield of winter wheat, in some years reaching values of 1.08-1.29 ton/ha. Improving the conditions of mineral nutrition by introducing balanced doses of fertilizers for all elements contributed to a sufficiently high yield. When applying the minimal doses of complete mineral fertilizer, the amount of winter wheat grain yield from 1 ha increased in grain tillage rotation to 4.70 ton/ha, including for predecessors from 4.07 to 5.38 ton/ha. In grain-grass tillage rotation, according to the placement in the crop rotation, it was from 4.43 to $6.17 \mathrm{ton} / \mathrm{ha}$, with an average indicator of $5.28 \mathrm{ton} / \mathrm{ha}$. During the years of the study, the increase in yields with the use of this fertilizer system on average amounted to $0.90-1.23$ ton/ha or to $20.5-35.4 \%$ in comparison with control options.

Increasing doses of fertilizer two times from the minimal one provided for the yield of winter wheat in the range of 5.52-6.31 and 5.55-6.36 ton/ha with the average indicator in this fertilizer system of 5.88-5.93 ton/ha. In comparison with the control option, the increase according to the crop rotation was 2.41-1.85 ton/ha or $69.4-35.4 \%$, and with a minimal dose, the growth of yield was at the level of 1.18-0.65 ton/ha. In our experiments, the payment for $1 \mathrm{~kg}$ of fertilizer in the current matter of the produced grain varied within wide limits and depended on the studied technological methods. It was distributed in the following sequence of predecessors: peas, sugar beet, maize, sainfoin and winter wheat (Table 2).

Table 2: The payback of fertilizers by grain of winter wheat, depending on the predecessor and the fertilizer system in various crop rotations, $\mathrm{kg} / \mathrm{kg}$

\begin{tabular}{|c|c|c|c|c|c|}
\hline \multirow{2}{*}{ Fertilizer system } & \multicolumn{4}{|c|}{ Predecessor } & \multirow{2}{*}{ Average in fertilizer system } \\
\hline & maize, sainfoin & winter wheat & peas & sugar beet & \\
\hline \multicolumn{6}{|c|}{ grain tillage rotation } \\
\hline Without fertilizers (control) & & & & & \\
\hline Average dose of PK & 6.42 & 9.83 & 34.0 & 5.83 & 14.02 \\
\hline Average dose of NK & 11.58 & 9.58 & 34.0 & 11.00 & 16.54 \\
\hline Average dose of NP & 19.75 & 17.17 & 23.50 & 19.60 & 20.00 \\
\hline Minimal dose of NPK & 13.67 & 16.00 & 36.67 & 15.87 & 20.55 \\
\hline Average dose of NPK & 13.89 & 13.05 & 26.67 & 13.62 & 16.81 \\
\hline Elevated dose of NPK & 13.75 & 10.75 & 21.75 & 15.25 & 15.37 \\
\hline High dose of NPK & 8.92 & 6.55 & 13.83 & 9.16 & 9.61 \\
\hline Average for the predecessor & 12.57 & 11.85 & 27.20 & 12.90 & \\
\hline \multirow{2}{*}{\multicolumn{6}{|c|}{ grain-grass tillage rotation }} \\
\hline Without fertilizers (control) & & & & & \\
\hline Average dose of PK & 17.00 & 8.08 & 28.00 & 5.75 & 14.71 \\
\hline Average dose of NK & 10.0 & 4.67 & 26.00 & 9.00 & 12.42 \\
\hline Average dose of NP & 9.67 & 10.33 & 17.67 & 17.60 & 13.82 \\
\hline Minimal dose of NPK & 10.33 & 10.11 & 28.67 & 13.50 & 15.65 \\
\hline Average dose of NPK & 14.00 & 7.83 & 21.33 & 12.69 & 13.96 \\
\hline Elevated dose of NPK & 9.25 & 7.04 & 21.37 & 12.80 & 12.61 \\
\hline High dose of NPK & 6.17 & 4.61 & 12.67 & 7.97 & 7.85 \\
\hline Average for the predecessor & 10.92 & 7.52 & 22.24 & 19.83 & \\
\hline
\end{tabular}

With identical fertilizer systems for sainfoin and peas as predecessors, a higher increase in primary production per $1 \mathrm{~kg}$ of fertilizers was obtained by placing winter wheat on peas: $13.83-36.67 \mathrm{~kg}$ and $12.67-28.67 \mathrm{~kg}$

Mineral fertilizers, introduced in different quantities and combinations, affected the payback in different ways by an increase in grain. As fertilizer doses increased, the yield of winter wheat was also higher, and the payback by additional grain harvest decreased The lowest payback of fertilizers with an additional yield was obtained at elevated and high doses of complete mineral fertilizer. On average, for 7 years of research it was 9.61-15.37 and 7.85$12.61 \mathrm{~kg} / \mathrm{kg}$. In options with a pair combination of fertilizers by 
nutrient elements, the combinations of $\mathrm{NK}$ and $\mathrm{NP}$ equaling to $16.54-20.0 \mathrm{~kg} / \mathrm{kg}$ were the most effective for this economic indicator in grain tillage rotation, and in grain-grass tillage rotation the combinations of PK and NP were equaling to $14.71-13.82 \mathrm{~kg} / \mathrm{kg}$. One of the criteria that make it possible to identify the effectiveness of various agricultural and technical methods that ensure an increase in yield is the economic efficiency in monetary terms.
If for the cost of the gross output on an unfertilized option one takes a spiked predecessor of 20.55-17.90 thousand rubles/ha as the standard, then this economic indicator would be $2.65-5.70$ thousand rubles/ha higher in comparison with such predecessors as maize and sugar beet and 2.25-6.50 thousand rubles/ha lower in reference to sainfoin and peas (Table 3).

Table 3: Gross value of winter wheat grain in various crop rotations depending on the predecessor and a fertilizer system, thousand rubles/ha

\begin{tabular}{|c|c|c|c|c|}
\hline \multirow{2}{*}{ Fertilizer system } & \multicolumn{4}{|c|}{ Predecessor } \\
\hline & maize, sainfoin & winter wheat & peas & sugar beet \\
\hline \multicolumn{5}{|c|}{ grain tillage rotation } \\
\hline Without fertilizers (control) & 12.20 & 17.90 & 21.40 & 15.25 \\
\hline Average dose of PK & 15.70 & 23.80 & 28.20 & 18.75 \\
\hline Average dose of NK & 19.15 & 23.65 & 24.80 & 20.75 \\
\hline Average dose of NP & 24.05 & 28.20 & 28.45 & 25.05 \\
\hline Minimal dose of NPK & 18.35 & 25.10 & 26.90 & 21.60 \\
\hline Average dose of NPK & 24.70 & 29.65 & 29.40 & 26.15 \\
\hline Elevated dose of NPK & 28.70 & 30.80 & 30.10 & 30.50 \\
\hline High dose of NPK & 28.25 & 29.70 & 29.70 & 29.90 \\
\hline Average for the predecessor & 21.39 & 26.10 & 27.37 & 23.49 \\
\hline \multicolumn{5}{|c|}{ grain-grass tillage rotation } \\
\hline Without fertilizers (control) & 27.05 & 20.55 & 22.80 & 16.75 \\
\hline Average dose of PK & 30.42 & 25.40 & 28.40 & 20.20 \\
\hline Average dose of NK & 27.15 & 23.35 & 25.40 & 21.25 \\
\hline Average dose of NP & 29.95 & 26.75 & 28.10 & 25.55 \\
\hline Minimal dose of NPK & 28.60 & 25.10 & 27.10 & 22.15 \\
\hline Average dose of NPK & 31.25 & 27.60 & 29.20 & 26.90 \\
\hline Elevated dose of NPK & 30.75 & 29.00 & 31.35 & 29.55 \\
\hline High dose of NPK & 30.75 & 28.85 & 30.40 & 29.50 \\
\hline Average for the predecessor & 29.49 & 25.82 & 27.84 & 23.98 \\
\hline
\end{tabular}

The fertilizer systems studied in crop rotations in comparison with the natural agrochemical background of nutrition increased the yield of winter wheat; they also increased the value of gross output on the average for predecessors of grain tillage rotation by 3.515.25 thousand rubles/ha, and of grain-grass tillage rotation - by $3.45-12.75$ thousand rubles/ha. The value of the predecessors increased with the elevation in fertilizer doses, but the same dependence remained as for the average indicators.

The highest value of gross output of 29.49 thousand rubles/ha was obtained for the predecessor of sainfoin, the lowest was 21.39 thousand rubles/ha for maize. Mineral fertilizers contributed to the growth of this economic indicator by $15.9-135.2 \%$ and 11.4$76.4 \%$ to the crop rotations, respectively, reaching a maximum level of 28.25-30.80 and 28.85-31.35 thousand rubles/ha for fertilizer systems with elevated $\left(\mathrm{N}_{40-120} \mathrm{P}_{40-60} \mathrm{~K}_{0-60}\right)$ and high $\left(\mathrm{N}_{40-120} \mathrm{P}_{80}\right.$ ${ }_{120} \mathrm{~K}_{0-120}$ ) fertilizer doses.

It has been established that the costs of aggregate energy were fully repaid by the output of gross energy in all options of the experiment, but their effectiveness was different. Thus, the predecessor of sainfoin had the most significant increment in total energy equaling to $136.8-185.65 \mathrm{GJ} / \mathrm{ha}$, while the maize predecessor had the lowest one - 66.56-161.14 GJ/ha (Table 4).

Table 4: Bioenergetic assessment of the cultivation of winter wheat in grain tillage crop rotation, depending on the predecessor and the fertilizer system

\begin{tabular}{|c|c|c|c|c|c|}
\hline \multirow{2}{*}{ Fertilizer system } & \multicolumn{4}{|c|}{ Predecessor } & \multirow{2}{*}{ Average in fertilizer system } \\
\hline & maize & winter wheat & peas & sugar beet & \\
\hline \multicolumn{6}{|c|}{ aggregate energy output, GJ/ha } \\
\hline Without fertilizers (control) & 82.42 & 119.48 & 142.98 & 101.83 & 116.68 \\
\hline Average dose of PK & 104.88 & 159.01 & 188.40 & 125.27 & 144.39 \\
\hline Average dose of NK & 127.84 & 157.87 & 165.58 & 138.61 & 147.47 \\
\hline Average dose of NP & 160.61 & 188.22 & 189.99 & 167.36 & 176.54 \\
\hline Minimal dose of NPK & 133.90 & 167.69 & 179.60 & 144.22 & 156.35 \\
\hline Average dose of NPK & 164.94 & 198.03 & 196.25 & 174.61 & 183.46 \\
\hline Elevated dose of NPK & 191.54 & 205.76 & 200.91 & 209.64 & 200.47 \\
\hline High dose of NPK & 188.42 & 198.35 & 198.35 & 199.62 & 196.26 \\
\hline \multicolumn{6}{|c|}{ increment of energy, GJ/ha } \\
\hline Without fertilizers (control) & 66.56 & 102.00 & 125.73 & 85.50 & 94.95 \\
\hline Average dose of PK & 87.12 & 139.15 & 168.87 & 106.85 & 128.21 \\
\hline Average dose of NK & 105.57 & 134.06 & 144.22 & 117.69 & 125.38 \\
\hline Average dose of NP & 136.76 & 163.41 & 167.23 & 144.96 & 153.09 \\
\hline Minimal dose of NPK & 113.49 & 145.91 & 159.65 & 124.10 & 135.79 \\
\hline Average dose of NPK & 140.46 & 171.96 & 173.85 & 151.51 & 159.44 \\
\hline Elevated dose of NPK & 161.14 & 174.21 & 179.81 & 176.16 & 172.83 \\
\hline High dose of NPK & 156.99 & 165.51 & 172.72 & 170.84 & 166.51 \\
\hline \multicolumn{6}{|c|}{ net efficiency ratio } \\
\hline Without fertilizers (control) & 4.20 & 5.83 & 7.29 & 5.23 & 5.64 \\
\hline Average dose of PK & 4.90 & 7.01 & 8.65 & 5.80 & 6.59 \\
\hline Average dose of NK & 4.74 & 5.69 & 6.75 & 5.62 & 5.68 \\
\hline Average dose of NP & 5.73 & 6.59 & 7.35 & 6.47 & 6.54 \\
\hline Minimal dose of NPK & 5.56 & 6.69 & 8.00 & 6.17 & 6.60 \\
\hline Average dose of NPK & 5.74 & 6.60 & 7.76 & 6.56 & 6.66 \\
\hline Elevated dose of NPK & 5.29 & 5.52 & 7.34 & 6.41 & 6.14 \\
\hline High dose of NPK & 4.95 & 5.06 & 6.62 & 5.94 & 5.64 \\
\hline
\end{tabular}


Despite a significant increase in aggregate energy costs by 1.13 1.78 times compared to the unfertilized option, mineral fertilizers contributed to a larger increment in gross energy, which elevated as fertilizer doses were increased. This indicator of bioenergetic efficiency was at the maximal level when introducing elevated doses of mineral fertilizers $\left(\mathrm{N}_{40} \mathrm{P}_{40}, \mathrm{~N}_{80} \mathrm{P}_{60} \mathrm{~K}_{60}\right.$ and $\left.\mathrm{N}_{120} \mathrm{P}_{60} \mathrm{~K}_{60}\right)$. In accordance with the crop rotations, it was expressed by the following values: $161.14-179.81 \mathrm{GJ} / \mathrm{ha}$ for grain tillage rotation, and 162.46-185.38 GJ/ha for grain-grass tillage rotation (Table 5).

Table 5: Bioenergetic assessment of the cultivation of winter wheat in grain grass tillage rotation, depending on the predecessor and the fertilizer system

\begin{tabular}{|c|c|c|c|c|c|}
\hline \multirow{2}{*}{ Fertilizer system } & \multicolumn{4}{|c|}{ Predecessor } & \multirow{2}{*}{ Average in fertilizer system } \\
\hline & sainfoin & winter wheat & peas & sugar beet & \\
\hline \multicolumn{6}{|c|}{ aggregate energy output, GJ/ha } \\
\hline Without fertilizers (control) & 155.84 & 137.41 & 152.55 & 111.99 & 139.44 \\
\hline Average dose of NK & 181.68 & 156.26 & 169.92 & 142.26 & 162.53 \\
\hline Average dose of NP & 200.34 & 178.93 & 187.94 & 170.88 & 184.52 \\
\hline Minimal dose of NPK & 191.32 & 168.00 & 181.36 & 148.20 & 172.22 \\
\hline Average dose of NPK & 208.99 & 184.74 & 195.35 & 179.90 & 192.24 \\
\hline Elevated dose of NPK & 205.83 & 194.07 & 209.66 & 197.77 & 201.83 \\
\hline High dose of NPK & 205.77 & 193.11 & 203.39 & 197.46 & 199.93 \\
\hline \multicolumn{6}{|c|}{ increment of energy, GJ/ha } \\
\hline Without fertilizers (control) & 136.80 & 119.21 & 135.88 & 95.40 & 121.82 \\
\hline Average dose of PK & 183.10 & 149.49 & 170.44 & 116.71 & 154.93 \\
\hline Average dose of NK & 159.40 & 132.17 & 148.55 & 121.27 & 140.35 \\
\hline Average dose of NP & 176.19 & 154.02 & 165.23 & 148.40 & 160.96 \\
\hline Minimal dose of NPK & 169.95 & 145.89 & 161.33 & 127.96 & 151.28 \\
\hline Elevated dose of NPK & 180.98 & 162.46 & 185.38 & 169.91 & 174.68 \\
\hline High dose of NPK & 178.86 & 160.16 & 177.16 & 168.64 & 171.20 \\
\hline \multicolumn{6}{|c|}{ net efficiency ratio } \\
\hline Without fertilizers (control) & 7.18 & 6.55 & 8.16 & 5.76 & 6.91 \\
\hline Average dose of PK & 8.88 & 7.32 & 8.71 & 6.32 & 7.84 \\
\hline Average dose of NK & 7.15 & 5.49 & 6.95 & 5.78 & 6.34 \\
\hline Average dose of NP & 7.30 & 6.18 & 7.28 & 6.60 & 6.84 \\
\hline Minimal dose of NPK & 7.95 & 6.60 & 8.05 & 6.32 & 7.23 \\
\hline Average dose of NPK & 7.95 & 6.07 & 7.72 & 6.69 & 7.11 \\
\hline Elevated dose of NPK & 7.28 & 5.14 & 7.63 & 6.10 & 6.54 \\
\hline High dose of NPK & 6.65 & 4.86 & 6.78 & 5.85 & 6.03 \\
\hline
\end{tabular}

When assessing the role of crop rotations in the impact on the gross energy output and other bioenergetic indicators, it should be noted that there is the advantage of grain-grass tillage rotation Accordingly, for the main bioenergetic indicators, these differences amounted to $1.7-21.1 \%, 1.0-28.3 \%$ and $6.5-22.5 \%$.

The indicator of energy efficiency is considered to be the main criterion for the energy assessment of methods for cultivating agricultural crops, since it takes into account the energy consumed for production and the energy contained in the final product. The conducted research and calculations showed that almost all the examined fertilizer systems provided a sufficiently high energy efficiency coefficient, which was adequate to the natural agrochemical background. This indicator was slightly lower in both rotations with winter wheat and peas as predecessors and with the use of nitrogen-potassium fertilizers, elevated and high doses of complete mineral fertilizer.

The coefficient of net energy efficiency permitted to distinguish options with minimum fertilizer costs, where a high coefficient of net efficiency of 6.17-8.00 and 6.32-8.05 was obtained with lower yields and energy accumulated in the production. The increase in fertilizer costs leads to a decrease in this indicator by $7.6-14.54 \%$ and $1.7-16.6 \%$.

A similar dependence can also be observed when calculating the yield of grain by 1 GJ of expended energy. With improved nutrition conditions, the yield of grain per unit of invested energy or the energy cost in comparison with the unfertilized option increased by $1.2-18.8 \%$ and $2.9-6.9 \%$, and decreased with an average dose of $4.2-15.7 \%$ and $3.8-12.4 \%$, while the yield of grain per unit of expended direct labor increased accordingly to the rotation and predecessors from 289.1-507.1 and 396.9-636.5 $\mathrm{kg} /$ person/hour at an unfertilized option up to 680.1-724.7 and $682.3-742.9 \mathrm{~kg} /$ person/hour with the introduction of an elevated dose of complete mineral fertilizer.

Based on the obtained results and the performed calculations, it follows that fertilizers influenced the energy efficiency indicators, increasing energy costs by 12.2-78.2\% compared to the control option, and increased the accumulation by the yield by $5.8-46.7 \%$ and $16.5-44.7 \%$, net energy income - by $32.0-82.0 \%$ and $15.2-$ $43.4 \%$, reducing the energy cost of production by $5.4-15.3 \%$ and $1.2-5.9 \%$. At the same time, the lower energy cost of production was in grass crop rotation.

In years with insufficient water availability and absence of epiphytoties of leaf and root diseases, the spiked predecessor (winter wheat) provides a sufficiently high yield with high economic and bioenergetic efficiency indicators.

The predecessors of sainfoin and winter wheat are more energyintensive in terms of the costs of combustive and lubricating materials and other energy carriers. According to the cost of liquid fuel per ton of grain, peas as the predecessor with the values of 13.3$17.9 \mathrm{~kg}$ and $12.48-17.35 \mathrm{~kg}$ is more economical; in the second place there are sainfoin (15.35-18.29 kg/ton) and sugar beet (12.8$25.9 \mathrm{~kg} /$ ton). Maize and winter wheat are the most expensive.

For all examined predecessors, average doses of complete mineral fertilizer are preferred. The increase in the fertilizer rate by 2 times from the average in terms of economic and bioenergetic assessment is ineffective. With a significant increase in all costs, the coefficient of net bioenergetic efficiency here is much lower. The payback of $1 \mathrm{GJ}$ of grain is also at a lower level.

\section{Conclusion}

The introduction of fertilizers, balanced for all elements, contributed to a sufficiently high yield. The increase in yield with the use of the fertilizer systems was on average by $20.5 \%-70.0 \%$ over the years of study as compared with the control options.

From the point of view of bioenergetic and economic efficiency, such predecessors as sainfoin, winter wheat, sainfoin for the turnover layer and peas should be considered as the most favorable ones for the cultivation of winter wheat. Tillage predecessors are 
more energy consuming - maize harvested for grain and sugar beet. According to labor costs and costs of combustive and lubricating materials per 1 ton of manufactured products, one should distinguish sainfoin cropped fallow and the spiked one with the soil, treated with clover fallow. Among the fertilizer systems used, the best economic and bioenergetic indicators were obtained using average and higher doses of complete mineral fertilizer.

Fertilizer systems unbalanced in nitrogen, phosphorus and potassium are costlier in terms of direct labor, consumption of combustive and lubricating materials, and according to the output of aggregate energy per unit area, they are less effective.

\section{References}

[1] Gorpinchenko KN (2007), Effektivnost tekhnologii vyrashchivaniya ozimoi pshenitsy [Efficiency of Winter Wheat Growing Technologies] Ekonomika selskogo khozyaistva Rossii 5, 35-36.

[2] Gorpinchenko KN (2012), Osobennosti prognozirovaniya proizvodstva zerna [Features of Predicting the Grain Production]. Ekonomika selskokhozyaistvennykh i pererabatyvayushchikh predpriyatii 4, 46-49.

[3] Korobko AN, Orlenko SYu, Trubilin AI, Neshchadim N.N. et al (2015), Sistema zemledeliya Krasnodarskogo kraya na aerolandshaftnoi osnove [The System of Agriculture of Krasnodar Krai on an Air-Landscaping Basis]. Krasnodar.

[4] Soon YK \& Clayton GW (2002), Eight Years of Crop Rotation and Tillage Effects on Crop Production and N-Fertilizer Use. Canadian Journal of Soil Science 82(2), 165-172.

[5] Bespalova LA (2015), Razvitie genofonda kak glavnyi faktor tretei zelenoi revolyutsii $\mathrm{v}$ selektsii pshenitsy [The Development of the Gene Pool as the Main Factor in the Third Green Revolution in the Wheat Selection]. Vestnik Rossiiskoi akademii nauk 85(1), 9-11.

[6] Prudnikov AG \& Gorpinchenko KN (2013), Formirovanie zatrat na sozdanie novogo sorta (gibrida) zernovykh kultur [Formation of Expenses on Creation of a New Variety (Hybrid) of Crops]. V mire nauchnykh otkrytii 8.1(44), 293-305.

[7] Barshadskaya SI, Kvashin AA, Gorpinchenko KN \& Dereka FI (2016), Effektivnost vyrashchivaniya razlichnykh sortov ozimoi pshenitsy v usloviyakh nedostatochnogo uvlazhneniya Krasnodarskogo kraya [Efficiency of Cultivating Varieties of Winter Wheat under Conditions of Insufficient Moistening of Krasnodar Krai]. Politematicheskii setevoi zhurnal Kubanskogo gosudarstvennogo agrarnogo universiteta 120,1322-1336.

[8] Malyuga NG, Neshchadim NN, Garkusha SV \& Petrik GF (2012), Vliyanie priemov vyrashchivaniya na soderzhanie osnovnykh elementov pitaniya, tyazhelykh metallov v pochve i urozhainost zerna ozimoi pshenitsy v tsentralnoi zone Krasnodarskogo kraya [Growing Methods Impact on Basic Nutrients and Heavy Metal Content in Soil and Winter Wheat Grain Yielding in the Central Zone of Krasnodar Krai]. Trudy Kubanskogo gosudarstvennogo agrarnogo universiteta $35,135-142$.

[9] Neshchadim NN, Gorpinchenko KN \& Kvashin AA (2012), Sovremennye problemy kachestva zerna [Modern Problems of Grain Quality]. Trudy Kubanskogo gosudarstvennogo agrarnogo universiteta 35, 338-342.

[10] Gorpinchenko KN (2013), Tekhnicheskaya modernizatsiya zernovogo proizvodstva v Krasnodarskom krae [Technical Modernization of Grain Production in Krasnodar Krai]. Nauka i mir 2(2), 85-88.

[11] Thomason WE, Raun WR, Johnson GV, Freeman KW, Wynn KJ \& Mullen RW (2002), Production System Techniques to Increase Nitrogen Use Efficiency in Winter Wheat. Journal of Plant Nutrition 25(10), 2261-2283

[12] Jönsson JO \& Eriksson J (2003), The Effect of Fertilization for Higher Protein Content of Cd-Level in Winter Wheat Grain. In 7th International Conference on the Biogeochemistry of Trace Elements, Uppsala '03, Conference Proceedings 3, 242-243. Uppsale, Sweden: SLU Service.

[13] Filgueiras AV, Lavilla I \& Bendicho C (2002), Chemical Sequential Extraction for Metal Partitioning in Environmental Soil Samples. Journal of Environmental Monitoring 4, 823-857.

[14] Kvashin AA, Barshadskaya SI \& Dereka FI (2011), Plodorodie chernozema obyknovennogo i produktivnost selskokhozyaistvennykh kultur [Fertility of Ordinary Chernozem and Productivity of Agricultural Crops]. Plodorodie 2, 36-39.

[15] Sheudzhen AKh, Neshchadim NN \& Onishchenko LM (2011), Organicheskoe veshchestvo pochvy i ego ekologicheskie funktsii [Organic Matter of the Soil and Its Ecological Functions]. Krasnodar.
[16] Shtompel YuA, Neshchadim NN \& Lebedovskii IA (2009), Otsenka kachestva pochv, puti vosproizvodstva plodorodiya ikh $i$ ratsionalnogo ispolzovaniya: uchebnik [Assessment of Soil Quality, Ways of Reproducing Its Fertility and Rational Use: A Textbook]. Krasnodar.

[17] Trubilin IT (2002), Agroklimaticheskii monitoring $v$ zemledelii Krasnodarskogo kraya [Agroclimatic Monitoring in the Agriculture of Krasnodar Krai]. Krasnodar.

[18] Zakharchenko AV (2003), Teoreticheskie osnovy energeticheskoi otsenki vozdelyvaniya kultur [Theoretical Basis of Energy Assessment of Crop Cultivation]. Izvestiya TSKhA 1, 72-92. 